\title{
FAKTOR-FAKTOR YANG BERHUBUNGAN DENGAN KELENGKAPAN IMUNISASI DASAR PADA BALITA DI WILAYAH KERJA PUSKESMAS KOLOK KOTA SAWAHLUNTO
}

\author{
KURNIATI MAYA SARI, WD \\ Pengajar Akper YPTK Solok
}

\begin{abstract}
Immunization comes from the words immune, immune and resistant. Children are immunized, meaning they are given immunity against certain diseases. Children are immune or resistant to one disease but not necessarily immune to other diseases. So, immunization is an effort to actively generate / increase a person's immunity against a disease, so that if one day they are exposed to the disease, they will not get sick or only experience mild illness. The achievement of basic immunization in the working area of PuskesmasKolok is currently still low (67.3\%) compared to other Puskesmas in Sawahlunto City. This study aims to determine the factors related to the completeness of basic immunization for children under five in the Work Area of PuskesmasKolok Kota Sawahlunto in 2017. This type of research is descriptive analytic. This research was conducted in the working area of PuskesmasKolok, Sawahlunto City on 11 to 15 December 2017. The population in this study were all mothers who had toddlers aged 12-23 months. A total of 61 respondents. Data were collected through interviews using a questionnaire. Then the data is processed using computerization, then analyzed by univariate and bivariate after that it is interpreted. The results of the study more than half $(76 \%)$ of respondents have poor knowledge, more than half (72.2\%) of respondents have a job, more than some (84.4\%) of respondents have no family support, there is a significant relationship between maternal knowledge With the completeness of basic immunization for children under five, there is a significant relationship between the work status of the mother and the completeness of basic immunization for children under five, and there is a significant relationship between family support and completeness of basic immunization for children under five in the Work Area of PuskesmasKolok Kota Sawahlunto in 2017. It is hoped that the officers will increase regular outreach on every community activity such as posyandu about the impact of not immunizing babies. In the working area of Puskesmas Kolok, Sawahlunto City. Keywords: Immune, Children, Puskesmas Kolok, Sawahlunto City.
\end{abstract}

\section{A. Pendahuluan}

Anak merupakan buah hati yang sangat berharga bagi orang tuanya karena anaklah yang akan menggantikannya dikemudian hari itulah sebabnya anak sering disebut sebagai penerus bangsa yang berkualitas kita harus mempersiapkan anakanak yang sehat, baik pisik, mental, maupun social. Hanya dengan cara inilah para penerus bangsa ini bias bermamfaat bagi bangsa dan negaranya. Untuk mencapai hal ini, kita perlu melakukan upaya pencegahan melalui program imunisasi, disamping segera mengobatinya ketika mereka sakit. Ini merupakan Salah satu bentuk upaya pelayanan peningkatan kesehatan dengan preventif yaitu dengan imunisasi. (IDAI, 2014). 
Imunisasi merupakan salah satu cara yang efektif dan episien dalam mencegah penyakit dan merupakan bagian kedokteran prepensif yang mendapatkan prioritas. Sampai saat ini ada tujuh penyakit infeksi pada anak yang dapat menyebabkan kematian dan cacat, walau pun sebaian anak dapat bertahan dan menjadi kebal. Ketujuh penyakit tersebut dimasukkan kepada program imunisasi yaitu penyakit tuberculosis, difteri, pertusis, tetanus, polio, campak dan Hepatitis B. (Dwi Maryanti,2011). Imunisasi bertujuan untuk merangsang system imunilogi tubuh untuk membentuk anti bodi spesifik sehingga dapat melindungi tubuh dari serangan penyakit. Walau pun cakupan imunisasi tidak sama dengan $100 \%$ tetapi sudah mencapai $70 \%$ maka anak-anak yang tidak mendapatkan imunisasi pun akan terlindungi oleh adanya suatu" herd immunity". (Dwi Maryanti,2011).

Imunisasi merupakan salah satu investasi kesehatan yang paling cost-effective (murah),karena terbukti dapat mencegah dan mengurangi kejadian sakit,cacat, dan kematian akibat PD3I yang diperkirakan 2 hingga 3 juta kematian tiap tahunnya ( PUSDATIN,kemenkes ,2016).Selanjutnya didalam kepmenkes RI tentang pedoman penyelenggaraan imunisasi disebutkan bahwa imunisasi merupakan salah satu upaya preventif untuk mencegah penyakit melalui pemberian kekebalan teguh harus dilaksanakan secara terus menerus,menyeluruh dan dilaksanakan sesuai standar sehingga mampu memberikan perlindungan kesehatan. Badan kesehatan dunia (WHO) merekomendasikan 25 vaksin untuk penggunaaan rutin bagi anakanak, remaja dan dewasa. Statistik menunjukan bahwa hampir $85 \%$ bayi di dunia menerima vaksinasi lengkap. Hal ini sangat menggembirakan dan focus kita sekarang adalah membuatnya menjadi $100 \%$. Terdapat 18,7 juta anak yang tidak mendapat vaksinasi/ mendapat vaksinasi tetapi tidak lengkap. Sebagai informasi tambahan sekitar 3,7 juta anak ini hidup di 9 wilayah dampak konflik, pengungsian dan daerah terlantar di timur tengah. ( IDAI, 2016).

Program imunisasi pada bayi bertujuan agar setiap bayi mendapatkan imunisasi dasar secara lengkap.keberhasilan seorang bayi dalam mendapatkan imunisasi dasar tersebut diukur melalui indicator imunisasi dasar lengkap. Capaian indicator ini di Indonesia pada tahun 2015 sebesar 86,54 \%. Angka ini belum mencapai target renstra tahun 2015 (kemenkes RI, 2016). Pada tahun 2014 diperkirakan lebih dari 104.040 balita di Sumatera Barat telah di vaksinasi dibandingkan tahun 2013, akan tetapi diperkirakan 19,3 juta balita di seluruh dunia masih tidak terjangkau oleh layanan imunisasi rutin.. Cakupan Lima Imunisasi dasar Lengkap (LIL) di Indonesia meliputi imunisasi BCG, DPT+HB, Polio, Campak dan HB. Tahun 2014 Pencapaian UCI masih terbilang rendah karena baru mencapai 69,8\% ( Kemenkes RI: 2014 ).

Menurut data cakupan imunisasi Kota Sawalunto Provinsi Sumatera Barat dapat dilihat pada table berikut.:

Cakupan Imunisasi Lengkap Seluruh Puskesmas Kota Sawahlunto

\begin{tabular}{|c|c|c|c|c|c|c|}
\hline \multirow{2}{*}{ NO } & \multirow{2}{*}{ PUSKESMAS } & \multicolumn{3}{|c|}{ BAYI BARU LAHIR } & \multicolumn{2}{c|}{$\begin{array}{c}\text { IMUNISASI } \\
\text { LENGKAP }\end{array}$} \\
\cline { 3 - 7 } & & $\mathrm{L}$ & $\mathrm{P}$ & JML & JML & $\%$ \\
\hline 1 & TALAWI & 197 & 190 & 386 & 330 & 85,4 \\
\hline 2 & KOLOK & 68 & 70 & 138 & 93 & 67,3 \\
\hline
\end{tabular}




\begin{tabular}{|c|c|c|c|c|c|c|}
\hline 3 & S.DURIAN & 95 & 95 & 191 & 152 & 79,7 \\
\hline 4 & LUNTO & 43 & 47 & 90 & 71 & 79,3 \\
\hline 5 & KP.TELENG & 77 & 78 & 155 & 107 & 69,2 \\
\hline 6 & SILUNGKANG & 112 & 114 & 226 & 169 & 74,9 \\
\hline \multicolumn{7}{|l}{} \\
\hline
\end{tabular}

Sumber : laporan dinas kesehatan kota sawahlunto

Berdasarkan data diatas dapat disimpulkan dari 6 Puskesmas yang ada di Sawahlunto, Puskesmas Kolok yang paling rendah pencapaian imunisasi dasarnya $67,3 \%$, ini masih dibawah target imunisasi dasar di kota Sawahlunto yaitu 77,8\%. Menurut Ikatan Dokter Anak Indonesia, kalau anak tidak diberikan imunisasi dasar lengkap, maka tubuhnya tidak mempunyai kekebalan yang spesifik terhadap penyakit tersebut. Bila kuman berbahaya yang masuk cukup banyak maka tubuhnya tidak mampu melawan kuman tersebut sehingga bisa menyebabkan sakit berat, cacat atau meninggal. Oleh karena itu bila orang tua tidak mau anaknya di imunisasi berarti bisa membahayakan anaknya dan anak-anak lain disekitarnya. Karena mudah tertular penyakit bebahaya yang dapat menimbulkan sakit berat, cacat atau kematian. (IDAI, 2013).

Menurut teori green kesehatan seseorang dipengaruhi oleh dua faktor yaitu factor perilaku dan factor di luar perilaku. Seseorang yang tidak mau mengimunisasikan anaknya di posyandu dapat disebabkan karena orang tersebut tidak tau atau belum mengetahui ,manfaat imunisasi bagi anaknya. Atau batang kali juga karena rumahnya jauh dari posyandu atau puskesmas tempat mengimunisasikan anaknya. Sebab lain, mungkin para petugas kesehatan atau tokoh masyarakat lain disekitarnya tidak pernah mengimunisasikan anaknya.( Notoatmodjo, 2012). Beberapa faktor diduga berperan dalam pemberian imunisasi dasar di antaranya pendidikan, status pekerjaan, jumlah anak, pegetahuan ibu tentang imunisasi, motivasi keluarga, persepsi akan manfaat, dukungan keluarga, usia ibu, sikap petugas dan lokasi tempat imunisasi ( Rahmawati, 2014). Pengetahuan ibu tentang imunisasi yang baik mempengaruhi motivasi ibu dalam mengimunisasikan anaknya.

\section{B. Metodologi Penelitian}

Penelitian ini bersifat deskriptif analitik dengan pendekatan cross sectional. Data yang diperoleh adalah data sekunder yang dikumpulkan dari laporan petugas program dipuskesmas. Populasi pada penelitian ini adalah seluruh ibu yang mempunyai balita di wilayah kerja Puskesmas Kolok Kota Sawahlunto yang berjumlah 110 orang. Dari 110 orang anak yang rentang usia 12-23 bulan yang berjumlah 61. Jadi, seluruh populasi peneliti jadikan sebagai sambel yang berjumlah 61 orang anak.

\section{Hasil dan Pembahasan \\ 1. Hasil}

\section{Imunisasi Dasar}

Distribusi Frekuensi Responden Berdasarkan Imunisasi Dasar Di Wilayah Kerja Puskesmas Kolok Kota Sawahlunto Tahun 2017 


\begin{tabular}{|l|c|l|}
\hline Imunisasi Dasar & Frekuensi & \% \\
\hline Lengkap & 27 & 44,3 \\
& 34 & 55,7 \\
\hline Tidak lengkap & $\mathbf{6 1}$ & $\mathbf{1 0 0}$ \\
\hline Total & & \\
\hline
\end{tabular}

Berdasarkan data di atas dapat dilihat lebih dari sebagian $(55,7 \%)$ responden tidak lengkap imunisasi dasarnya, di wilayah Kerja Puskesmas Kolok Kota Sawahlunto.

\section{Pengetahuan Ibu}

Distribusi Frekuensi Responden Berdasarkan Pengetahua Di Wilayah Ker Puskesmas Kolok Kota Sawahlunto Tahun 2017

\begin{tabular}{|c|c|c|}
\hline Pengetahuan & Frekuensi & \% \\
\hline Baik & 36 & 59 \\
Kurang Baik & 25 & 41 \\
\hline Total & $\mathbf{6 1}$ & $\mathbf{1 0 0}$ \\
\hline
\end{tabular}

Berdasarkan tabel di atas terlihat bahwa lebih dari sebagian (59\%) responden memiliki pengetahuan yang baik tentang imunisasi dasar pada anak balita di wilayah Kerja Puskesmas Kolok Kota Sawahlunto.

\section{Pekerjaan Ibu}

Distribusi Frekuensi Responden Berdasarkan Pekerjaan Di Wilayah Keja

Puskesmas Kolok Kota Sawahlunto Tahun 2017

\begin{tabular}{|c|c|c|}
\hline Pekerjaan & Frekuensi & \% \\
\hline Bekerja & 36 & 59,1 \\
Tidak Bekerja & 25 & 40,9 \\
\hline Total & $\mathbf{6 1}$ & $\mathbf{1 0 0}$ \\
\hline
\end{tabular}

Berdasarkan tabel di atas dapat dilihat lebih dari sebagian ( 59,1\%) responden dikategorikan bekerja di Wilayah Kerja Puskesmas Kolok Kota Sawahlunto.

\section{Dukungan Keluarga}

Distribusi Frekuensi Responden Berdasarkan Dukungan Keluarga Di Wilayah Keja Puskesmas Kolok Kota Sawahlunto Tahun 2017

\begin{tabular}{|c|c|c|}
\hline Dukungan Keluarga & Frekuensi & \% \\
\hline Ada & 35 & 57,4 \\
Tidak Ada & 26 & 42,6 \\
\hline Total & $\mathbf{6 1}$ & $\mathbf{1 0 0}$ \\
\hline
\end{tabular}

Berdasarkan tabel di atas dapat dilihat lebih dari sebagian ( 57,4\%) responden ada mendapatkan dukungan keluarga, di wilayah Kerja Puskesmas Kolok Kota Sawahlunto. 


\section{Hubungan Pengetahuan Ibu dengan Kelengkapan Imunisasi Dasar}

Distribusi Frekuensi Responden Berdasarkan Hubungan Pengetahuan Ibu dengan Kelengkapan Imunisasi DasarDi Wilayah KejaPuskesmas Kolok Kota Sawahlunto Tahun 2017

\begin{tabular}{|c|c|c|c|c|c|c|}
\hline \multirow{2}{*}{$\begin{array}{c}\text { Pengetahuan } \\
\text { Ibu }\end{array}$} & \multicolumn{4}{|c|}{ Imunisasi Dasar } & \multicolumn{2}{c|}{ Total } \\
\cline { 2 - 7 } & \multicolumn{2}{|c|}{ Lengkap } & \multicolumn{2}{c|}{ Tidak Lengkap } & \multicolumn{2}{c|}{} \\
\cline { 2 - 7 } & $\mathbf{f}$ & $\mathbf{\%}$ & $\mathbf{f}$ & $\mathbf{\%}$ & $\mathbf{F}$ & \% \\
\hline Baik & 21 & 58,3 & 15 & 41,7 & 36 & 100 \\
\hline Kurang Baik & 6 & 24 & 19 & 76 & 25 & 100 \\
\hline Jumlah & 27 & 44,3 & 34 & 55,7 & 61 & 100 \\
\hline \\
$=4,4$
\end{tabular}

Berdasarkan tabel diatas dari 36 responden yang berpengetahuan baik lebih dari sebagian ( 58,3\%) lengkap imunisasi dasarnya sedangkan 25 orang responden yang berpengetahuan kurang baik lebih dari sebagian ( $76 \%$ ) tidak lengkap imunisasi dasarnya. Dari uji statistic yang dilakukan ternyata diperoleh p value $0,017<0,05$ berarti ada hubungan yang bermakna antara tingkat pengetahuan dengan kelengkapan imunisasi dasar pada anak balita di wilayah Kerja Puskesmas Kolok Kota SAwahlunto. Dengan Odds Ratio $(4,4)$ artinya responden yang berpengetahuan baik berpeluang 4 kali lengkap imunisasi dasarnya dibandingkan responden yang berpengetahuan kurang baik.

\section{Hubungan Status Pekerjaan Ibu dengan Kelengkapan Imunisasi Dasar}

Distribusi Frekuensi Responden Berdasarkan Hubungan Status Pekerjaan dengan Kelengkapan Imunisasi DasarDi Wilayah Keja Puskesmas Kolok Kota SawahluntoTahun 2017

\begin{tabular}{|c|c|c|c|c|c|c|}
\hline \multirow{3}{*}{$\begin{array}{c}\text { Status } \\
\text { Pekerjaan } \\
\text { Ibu }\end{array}$} & \multicolumn{4}{|c|}{ Imunisasi Dasar } & \multirow{2}{*}{\multicolumn{2}{|c|}{ Total }} \\
\hline & \multicolumn{2}{|c|}{ Lengkap } & \multicolumn{2}{|c|}{ Tidak Lengkap } & & \\
\hline & $\mathbf{f}$ & $\%$ & $\mathbf{F}$ & $\%$ & $\mathbf{F}$ & $\%$ \\
\hline Bekerja & 10 & 27,8 & 26 & 72,2 & 36 & 100 \\
\hline $\begin{array}{c}\text { Tidak } \\
\text { Bekerja }\end{array}$ & 17 & 68 & 8 & 32 & 25 & 100 \\
\hline Jumlah & 27 & 44,3 & 34 & 55,7 & 61 & 100 \\
\hline
\end{tabular}

Berdasarkan tabel diatas dari 36 responden yang bekerja kecil sekali ( $27,8 \%$ ) kelengkap imunisasi dasarnya sedangkan 25 orang responden yang tidak bekerja lebih dari sebagian ( 68\%) lengkap imunisasi dasarnya. Dari uji statistic yang dilakukan ternyata diperoleh $\mathrm{p}$ value $0,004<0,05$ berarti ada hubungan yang bermakna antara status pekerjaan ibu dengan kelengkapan imunisasi dasar pada anak balita di wilayah Kerja Puskesmas Kolok Kota SAwahlunto. Dengan Odds Ratio $(5,5)$ artinya responden yang bekerja berpeluang 6 kali lengkap imunisasi dasarnya dibandingkan responden yang tidak bekerja. 
Hubungan Dukungan Keluarga dengan Kelengkapan Imunisasi Dasar

Distribusi Frekuensi Responden Berdasarkan Hubungan Dukunga Keluarga Ibu dengan Kelengkapan Imunisasi Dasar Di Wilayah KejaPuskesmas Kolok Kota Sawahlunto Tahun 2017

\begin{tabular}{|c|c|c|c|c|c|c|}
\hline \multirow{2}{*}{$\begin{array}{c}\text { Dukungan } \\
\text { Keluarga }\end{array}$} & \multicolumn{3}{|c|}{ Imunisasi Dasar } & \multicolumn{3}{c|}{ Total } \\
\cline { 2 - 7 } & Lengkap & \multicolumn{2}{c|}{ Tidak Lengkap } & \multicolumn{1}{c|}{} \\
\cline { 2 - 7 } & F & \% & F & \% & F & \% \\
\hline Ada & 23 & 65,8 & 12 & 34,2 & 35 & 100 \\
\hline Tidak Ada & 4 & 15,4 & 22 & 84,6 & 26 & 100 \\
\hline Jumlah & 27 & 44,3 & 34 & 55,7 & 61 & 100 \\
\hline
\end{tabular}

Berdasarkan tabel diatas dari 35 responden yang mendapat dukungan keluarga lebih dari sebagian ( 65,8\%) lengkap imunisasi dasarnya sedangkan 26 orang responden yang tidak mendapat dukungan keluarga sebagian besar ( 84,6\%) tidak lengkap imunisasi dasarnya. Dari uji statistic yang dilakukan ternyata diperoleh $\mathrm{p}$ value $0,000<0,05$ berarti ada hubungan yang bermakna antara dukungan keluarga dengan kelengkapan imunisasi dasar pada anak balita di wilayah Kerja Puskesmas Kolok Kota SAwahlunto. Dengan Odds Ratio $(10,5)$ artinya responden yang ada dukungan keluarga berpeluang 11 kali lengkap imunisasi dasarnya dibandingkan responden yang tidak ada mendapatkan dukungan keluarga.

\section{Pembahasan}

\section{Hubungan Pengetahuan Ibu Dengan kelengkapan Imunisasi Dasar}

Dari uji statistic yang dilakukan ternyata diperoleh $\mathrm{p}$ value $0,017<0,05$ berarti ada hubungan yang bermakna antara tingkat pengetahuan dengan kelengkapan imunisasi dasar pada anak balita di wilayah Kerja Puskesmas Kolok Kota SAwahlunto. Dengan Odds Ratio $(4,4)$ artinya responden yang berpengetahuan baik berpeluang 4 kali lengkap imunisasi dasarnya dibandingkan responden yang berpengetahuan kurang baik. Pengetahuan merupakan penginderaan manusia, atau hasil tahu seseorang terhadap objek melalui indera yang dimilikinya (silvia momomuat : 2014). Menurut Dedi (2010) Kurangnya pengetahuan masyarakat terhadap kesehatan mereka tidak berperilaku sesuai dengan nilai kesehatan.

Hal ini sesuai dengan pendapat Rahmawati (2014) bahwa " terdapat pengaruh antara tingkat pengetahuan ibu terhadap kelengkapan imunisasi dasar pada bayi atau balita". Menurut Lutfhi (2014) menyatakan "adanya hubungan antara pengetahuan ibu dengan kelengkapan imunisasi dasar". Kenyataan dilapangan dari hasil data yang dikumpulkan menunjukkan bahwa responden yang memiliki pengetahuan kurang baik ternyata imunisasi dasarnya tidak lengkap, karena semakin tinggi pendidikan seseorang tentu mereka semakain tinggi pula tingkat pemahamannya termasuk juga pemahaman tentang imunisasi dasar. berdasarkan kuisioner masih ada responden yang belum paham tentang jenis imunisasi dasar, dampak serta jadwal dari imunisasi dasar tersebut. Serta pengetahuan responden 
juga dipengaruhi oleh pendidikan reposnden yang sebagaian besar memiliki latar belakang pendidikan dasar dan menengah.

\section{Hubungan Status Pekerjaan Ibu Dengan kelengkapan Imunisasi Dasar}

Dari uji statistic yang dilakukan ternyata diperoleh $p$ value $0,004<0,05$ berarti ada hubungan yang bermakna antara status pekerjaan ibu dengan kelengkapan imunisasi dasar pada anak balita di wilayah Kerja Puskesmas Kolok Kota SAwahlunto. Dengan Odds Ratio $(5,5)$ artinya responden yang bekerja berpeluang 6 kali lengkap imunisasi dasarnya dibandingkan responden yang tidak bekerja. Menurut Retnoningsih dan Rusmiati (2010) pekerjaan merupakan factor predisposisi dalam pemanfaatan pelayanan kesehatan.Status dan jenis pekerjaan ibu memberi pengaruh terhadap imunisasi. Ada kecenderungan situasi pekerjaan akan menimbulkan masalah kesehatan bagi seorang ibu dan anggota keluarganya. Situasi kerja akan menimbulkan kesibukan dalam pekerjaan sehingga seorang ibu cenderung memiliki waktu terbatas untuk merawat keluarganya.

Hal ini tidak sesuai dengan pendapat Chatarina (2014) bahwa " tidak adanya pengaruh antara status pekerjaan ibu dengan kelengkapan imunisasi dasar pada bayi atau balita. Dan menurut Ikawati (2011) yaitu dari hasil penelitian diperoleh bahwa bayi dengan status imunisasi lengkap maupun tidak lengkap sebagian besar memiliki status pekerjaan sebagai pekerja, sehingga dari hasil analisis status pekerjaan ibu berpengaruh terhadap status kelengkapan imunisasi dasar pada bayi atau balita. Kenyataan yang ditemukan di lapangan dari hasil data yang di kumpulkan menunjukkan bahwa responden yang bekerja ternyata imunisasi dasarnya anaknya tidak lengkap, disebabkan karena responden banyak yang terlalu sibuk bekerja dan susah untuk meluangkan waktu pada anaknya untuk di imunisasikan, sehingga anak tidak mendapatkan imunisasi dasar lengkap . pada saat penelitian peneliti menemukan hampir sebagian responden bekerja sebagai IRT yang menghasilkan uang, dengan pekerjaan seperti membuat anyaman bambu, jualan barang-barang rumah tangga dan kredit pakaian, karena terlalu sibuk dengan pekerjaan ibu susah untuk meluangkan waktu pada anaknya untuk di imunisasikan.

\section{Hubungan Dukungan Keluarga Dengan kelengkapan Imunisasi Dasar}

Dari uji statistic yang dilakukan ternyata diperoleh $\mathrm{p}$ value $0,000<0,05$ berarti ada hubungan yang bermakna antara dukungan keluarga dengan kelengkapan imunisasi dasar pada anak balita di wilayah Kerja Puskesmas Kolok Kota SAwahlunto. Dengan Odds Ratio (10,5) artinya responden yang ada dukungan keluarga berpeluang 11 kali lengkap imunisasi dasarnya dibandingkan responden yang tidak ada mendapatkan dukungan keluarga. Dukungan keluarga yaitu suatu bentuk bantuan yang diberikan salah satu anggota keluaga untuk memberi kenyamanan fisik dan psikologis pada saat sesorang mengalami sakit (Friedman, 2014:228). Hal ini sesuai dengan hasil penelitian Rahmawati (2014) “ terdapat pengaruh antara dukungan keluarga dengan kelengkapan imunisasi dasar pada balita. Dan menurut Elly Isrtiyati (2011) " terdapat hubungan antara dukungan keluarga dengan kelengkapan imunisasi dasar pada bayi atau balita.

Kenyataan yang ditemukan di lapangan dari hasil data yang dikumpulkan menunjukan bahwa responden yang tidak mendapatkan dukungan keluarga ternyata imunisasi dasar anaknya tidak lengkap, disebabkan karena sebagia besar 84,6\%

E-ISSN: 2657-0300 Lembaga Penelitian dan Penerbitan Hasil Penelitian Ensiklopedia 153


responden tidak ada dukungan keluarga dan tidak lengkap imunisasinya, karena berdasarkan hasil kuisioner masih ada responden yang belum paham efek samping pemberian imunisasi dasar, keluarga juga tidak memberikan dukungan kepada repsponden, dan keluarga juga tidak menemani responden membawa anaknya untuk di imunisasikan.

\section{Penutup}

Lebih dari sebagian $(55,7 \%)$ bayi responden tidak mendapatkan imunisasi dasar lengkap di wilayah kerja Puskesmas Kolok Kota Sawahlunto Tahun 2017. lebih dari sebagian (76\%) reponden memiliki pengetahuan kurang baik dengan imunisasi tidak lengkap di wilayah kerja Puskesmas Kolok Kota Sawahlunto Tahun 2017. Lebih dari sebagian $(72,2 \%)$ responden memiliki pekerjaan dengan imunisasi tidak lengkap di wilayah kerja Puskesmas Kolok Kota Sawahlunto Tahun 2017. Lebih dari sebagian (84,6\%) responden tidak ada dukungan keluarga dengan imunisasi tidak lengkap di wilayah kerja Puskesmas Kolok Kota Sawahlunto Tahun 2017. Terdapat hubungan yang bermakna antara pengetahuan ibu dengan kelengkapan imunisasi dasar di wilayah kerja Puskesmas Kolok Kota Sawahlunto Tahun 2017. Terdapat hubungan yang bermakna antara status pekerjaan ibu dengan kelengkapan imunisasi dasar di wilayah kerja Puskesmas Kolok Kota Sawahlunto Tahun 2017. Terdapat hubungan yang bermakna antara dukungan keluarga dengan kelengkapan imunisasi dasar di wilayah kerja Puskesmas Kolok Kota Sawahlunto Tahun 2017.

\section{Daftar Pustaka}

Dwi Maryanti, dkk. 2012. Buku Ajar Neonatus, Bayi dan Balita. Trans Info Media. Jakarta

Cut yanti, Fitri. 2013. Factor-faktor yang mempengaruhi Ibu dalam pemberian Imunisasi HB O pada Bayi Baru Lahir diwilayah kerja puskesmas Meureudu Kabupaten Pidie Jaya. Program Study Diploma III Kebidanan U'Budiyah. Banda Aceh

Kemenkes RI. 2016. profil Kesehatan Indonesia. Jakarta

Notoatmodjo, S. 2012. promosi Kesehatan dan Perilaku Kesehatan. Jakarta : Rineka Cipta

Notoatmodjo, S. 2012. Metode Penelitian Kesehatan. Jakarta : Rineka Cipta

PUSDATIN, Kemenkes RI. 2016. Situasi Imunisasi di Indonesia. Jakarta

Rahmawati. 2014. Factor yang mempengaruhi, kelengkapan imunisasi dasar di kelurahan krembangan utara. Departemen Epidemiologi Fakultas Kesehatan Masyarakat Unair.

Retnaningsih dan Rusmiati. 2014. Analisa Faktor Predisposisi yang Berhubungan dengan Perilaku Ibu dalam Pemberian Imunisasi Hepatitis B pada Bayi, jurnal pembangunan manusia Vol. 4. 11, Jakarta

Satgas Imunisasi IDAI. 2014. Panduan Imunisasi Anak. Jakarta

Silvia, dkk. 2014. Hubungan Tingkat Pengetahuan Ibu tentang pentingnya Imunisasi Campak dengan Kepatuhan Melaksanakan Imunisasi di Puskesmas Kamangkoan. Program Study Ilmu Keperawatan Fakultas Kedokteran Universitas Sam Ratulangi. Manado. 
Haryani, Sri, dkk. 2011. Hubungan antara Pengetahuan Ibu tentang Imunisasi dasar dengan Motivasi Ibu untuk memberikan Imunisasi kepada Bayi di Puskesmas Bawen Kecamatan Bawen. Program Study S1 Ilmu Keperawatan STIKES Telogorejo. Semarang

Sukidi, dkk. 2012. Factor-faktor yang berhubungan dengan status imunisasi dasar pada bayi usia $<1$ tahun. Jurnal kesehatan, Jakarta. 